\title{
Strategic Planning for Communities, Non-profit Organizations and Public Agencies ${ }^{1}$
}

Henry Cothran and Rodney Clouser ${ }^{2}$

\section{Introduction}

By failing to prepare, you are preparing to fail Benjamin Franklin

Suppose you want to take your family on a vacation. In preparation for the trip, what would you do? Few of us would begin that vacation without first thinking about a number of things, including what we would enjoy doing, how much we could afford to spend, where we would go, how we would get there, what we might do if forced to change our plans, etc. In other words, we would plan the trip so that our time would be well spent, within our budget, and the end result would be what we both expected and wanted it to be.

While we see the need to plan significant activities in our personal life, many of us do not see that same need in the organizations where we work. Many organizations operate from day to day without any idea of what or where they want to be six months or six years from now. As Yogi Berra said, "If you don't know where you are going, you will wind up somewhere else." One way of not winding up somewhere else is to follow an orderly planning process that addresses each aspect of an organization's purpose and operation.

\section{What Is Strategic Planning?}

A plan is a list of actions arranged in whatever sequence is thought likely to achieve an objective John Argenti

John Bryson (1995) defines strategic planning as "a disciplined effort to produce fundamental decisions and actions that shape and guide what an organization is, what it does, and why it does it." Put simply, strategic planning is a process to determine what your organization intends to do and how it intends to do it. It can be compared to a roadmap that is used to guide you from where you are to where you want to be. A strategic plan assumes that an organization must be responsive to an environment that is dynamic, often unpredictable, and almost always changing. Strategic planning is accomplished through a formal process that focuses on fundamental choices about an organization's:• Mission, vision, and values.

1. This is EDIS document FE648, a publication of the Food and Resource Economics Department, Florida Cooperative Extension Service, Institute of Food and Agricultural Sciences, University of Florida, Gainesville, FL. Published July 2006. Please visit the EDIS website at http://edis.ifas.ufl.edu.

2. Henry Cothran, Associate In, and Rodney Clouser, Professor, Food and Resource Economics Department, Florida Cooperative Extension Service, Institute of Food and Agricultural Sciences, University of Florida, Gainesville, FL.

The use of trade names in this publication is solely for the purpose of providing specific information. UF/IFAS does not guarantee or warranty the products named, and references to them in this publication does not signify our approval to the exclusion of other products of suitable composition.

The Institute of Food and Agricultural Sciences (IFAS) is an Equal Opportunity Institution authorized to provide research, educational information and other services only to individuals and institutions that function with non-discrimination with respect to race, creed, color, religion, age, disability, sex, sexual orientation, marital status, national origin, political opinions or affiliations. U.S. Department of Agriculture, Cooperative Extension Service, University of Florida, IFAS, Florida A. \& M. University Cooperative Extension Program, and Boards of County Commissioners Cooperating. Larry Arrington, Dean 
- Programs and services.

- Resources.

- Target audience.

- Place in the community.

Bryan Barry (1997) describes this as "finding the fit" among three forces - the organization's mission, the capabilities of the organization and external opportunities. This "fit" is achieved by answering three questions:

1. What do you hope to accomplish?

2. What is needed and feasible in your service area?

3. What are you capable of doing?

\section{Why Engage in Strategic Planning?}

If you don't know where you're going, any road will take you there - George Harrison

Studies have shown that planning positively influences organizational performance. Knowing this, some organizations plan on a regular basis. Other organizations wait until they are approaching or are already in a state of crisis, while some do not see the need to plan at all. However, failing to plan has been equated with planning to fail.

Every organization faces many challenges. From increased demand for services to competition to funding uncertainties and leadership changes, the need exists to periodically evaluate every organization's purpose and goals. Good planning: (1) focuses on the organization's challenges and identifies opportunities to address those challenges; (2) gives managers choices to address problems and opportunities; (3) forces thinking about the future; and (4) involves some sort of formal activity that addresses the ability of the organization to respond to its external environment, encourages employees and management to think and act in a deliberate and planned fashion, and improves decision making.

The benefits of strategic planning are many. Strategic planning focuses in part on learning about the organization and its surroundings. An organization that engages in the process will have an improved understanding of its current situation and potential future. As a result, the organization will become more efficient and more effective. Decision-making, based on coherent, defensible strategies, will be better. A focused organization may gain political support and become more effective in communicating its mission, vision, and values to the public and key stakeholders.

\section{What Is the Strategic Planning Process?}

It's not the plan that is important, it's the planning - Graeme Edwards

Much has been written about the strategic planning process. Often the authors provide a very detailed description of the process by identifying and describing specific, sequential steps. Questions are presented that, when answered, will aid in the completion of each step in the process. Key people are identified to include in the process. In some instances, you may even find that the process can be completed on paper by filling out pre-designed forms. All of these aides are designed to assist the strategic planning leader in managing the process, developing the plan, and establishing an implementation tracking and evaluation process. However, strategic planning is probably best not thought of as a strictly linear process. Just as strategic planning assumes the organization needs to be dynamic and creative, the strategic planning process also must be dynamic and creative. As the Alliance for Nonprofit Management (1998) notes, "Inevitably the process moves forward and back several times before arriving at the final set of decisions. Therefore, no one should be surprised if the process feels less like a comfortable trip on a commuter train, but rather like a ride on a roller coaster. But even roller coaster cars arrive at their destination, as long as they stay on track." While continually moving forward in the process, always be prepared to revisit earlier decisions based on new information and insights.

As noted above, there are a number of materials available that can guide an organization through a strategic planning process. In every case, however, the process seeks to answer three broad questions: Who are we? What do we want to be? How will we 
get from who we are to who we want to be? There are six broad tasks that must be accomplished to complete a strategic planning process.

\section{Task 1: Get Ready}

Before you begin a strategic planning process, it is important to make sure everyone involved in the process is committed to carrying it through to completion by securing an agreement from your governing board, key stakeholders, fellow employees, and sometimes a representative sample of the clientele you serve.

The planning process will be made easier if you also designate a group to serve as the strategic planning committee. While the size of the committee may vary, it is best to keep the group fairly small. This planning committee will guide the overall process and be responsible for producing the final plan. The planning committee is responsible for all of the pre-planning work and for establishing a timeline for the project to be completed. This committee might consider writing a brief report that traces the history of the organization and describes the current situation or issues that necessitate a strategic planning process. Additional activities that would also contribute to the situation statement paper include:

- Developing an organizational profile.

- Reviewing previous planning documents.

- Developing a funding history.

- Identifying internal and external stakeholders that need to be included in the planning process.

- Identifying current customers.

- Determining the need for outside assistance.

\section{Task 2: Review the Organization's Values, Mission, and Vision}

Central to every successful organization is a set of core values, a clear mission and a challenging vision.

\section{The Core Values Statement}

Values are those underlying principles that direct the way the organization acts. Values may not be written, but they exist in every organization and can be identified by observing the way those who are formally associated with the organization (board, staff, and volunteers) act in conducting the organization's business. Identifying the values of the organization is essential to the strategic planning process because values underlie the decision-making process. Values form the basis for the ethical standards of the organization and will determine how the organization acts toward its customers, competitors, employees, and those with whom it does business. While the organization may choose not to include a written values statement in its planning process, it is important to recognize that how the organization acts reflects its values whether or not those values are explicitly stated. Below are examples of core values statements.

\section{Kodak:}

- We show respect for the dignity of the individual.

- We uphold uncompromising integrity.

-We give and receive unquestionable trust.

- We prove and maintain constant credibility.

-We support continual improvement and personal renewal.

- We recognize and celebrate achievement.

\section{City of West Hollywood, California:}

- Respect and Support for People

- Responsiveness to the Public

- Idealism, Creativity and Innovation

- Quality of Residential Life

- Promote Economic Development

- Public Safety 
- Responsibility for the Environment

\section{The Mission Statement}

According to the Alliance for Nonprofit Management (1998), "A mission statement typically describes an organization in terms of its purpose, business and values." A mission statement then provides a summary of the what, how, and why of your work. It communicates the significance and meaning of your organization. Often it includes a reference to the organization's values. It should be developed based on an understanding of the formal and informal mandates of the organization. (Why does the organization exist? What is it that your customers expect you to do or to be?) It should be based on the values of the organization, stated in positive terms, focused on the needs the organization seeks to address and solve, specific to the organization and brief (NSBA, 1998). Below are examples of mission statements.

- Broward County (Florida) Division of Cultural Affairs: "Enhancing the cultural environment through development of the arts."

- The Farm Foundation: "To improve the economic and social well-being of U.S. agriculture and rural people by helping private and public sector decision-makers identify and understand forces that will shape the future."

- Cornell University Community and Rural Development Institute: "CaRDI works to enhance life quality and social and personal well-being for the people of New York State."

- Leadership Brevard: "Engaging and connecting leaders through networking, skills development, education on community issues and opportunities for increased civic involvement."

\section{The Vision Statement}

While a mission statement describes what you do, a vision statement describes how you will "look" when you achieve success in accomplishing your mission. A vision statement serves to guide the organization as it implements its strategic plan. A vision statement identifies the direction and purpose of the organization. According to Burt Nanus (1992), author and organizational theorist, "There is no more powerful engine driving an organization toward excellence and long-range success than an attractive, achievable, and worthwhile vision of the future, widely shared."

A vision statement then presents a picture of the future that your organization wants to create. It will be unique and may take some time to develop. It is probably best developed by a subcommittee of the planning committee and then circulated to the full committee for consideration, revision, and adoption. It should draw on the values and mission statements. Below are examples of vision statements:

- Human Resource Association of Greater Detroit: "To be recognized and respected as one of the premier associations of HR Professionals."

- Business Retention and Expansion International: "To become the internationally recognized organization of choice for educating, training and resources for BR\&E."

- Westin Hotels: "Year after year, Westin and its people will be regarded as the best and most sought-after hotel and resort management group in North America."

\section{Task 3: Assess the Current Situation}

At this point in the process, it is time to take a realistic look at the internal and external environment in which the organization operates. In the first stage of the process, historical information was assembled and stakeholders identified. During this stage, the planning committee seeks to identify the organization's strengths and weaknesses and to identify both internal and external opportunities and threats (SWOT analysis). This process is also sometimes called an "environmental scan."

The planning committee can:

- Identify future customers and stakeholders.

- Conduct stakeholder interviews.

- Evaluate the historical activity and impact of the organization. 
- Calculate the costs/benefits of programs.

- Identify competitor and complimentary agencies and services.

- Identify potential partners for future activity.

- Compare current operations against similar programs.

- Assess program quality.

- Assess future funding potential.

From these interviews and analyses, the committee should identify specific issues that should be addressed in the remainder of the planning process. It may also be necessary during this stage of the process to revisit either the mission or the vision, or both, of the organization and make appropriate adjustments.

\section{Task 4: Set Goals for the Future}

The key issues have been identified and the mission and vision revisited and affirmed. Taken together, the issues and vision will determine how the organization approaches the future. Goals for achieving the mission and vision of the organization are developed during this stage of the planning process.

A mission describes what an organization does. A vision describes what the organization aspires to be. A goal describes what the organization must do if it is to carry out its mission and achieve its vision. A goal is a statement of intent in both the short term and long term as the organization moves toward achieving its vision. Goals can be set for the overall organization, units within the organization, and individuals within the operating units. Goals at the organizational level are generally expressed in broad terms and increase in specificity as they are developed by units and individuals. Crafted in this fashion, goals provide an effective control mechanism that allows everyone to see how his/her efforts fit into the overall organization's operations. Moving from broad organizational goals to specific operational goals also allows for immediate measurement of progress and the opportunity to document and celebrate accomplishments along the way.

Goals should address the findings from the SWOT analysis. There are several criteria for developing a goal that will serve to ensure success in implementing and achieving the goal. One process to evaluate a goal is to use the acronym SMART. While the origin of the acronym is not known and different authors use different terms, a "smart" goal is

- Specific: provides a detailed description of what is to be accomplished.

- Measurable: has base-line data and accomplishment can be documented.

- Attainable: there is a realistic chance the goal can be accomplished.

- Relevant: appropriate to and consistent with the mission of the organization.

- Time-bound: clearly specifies when the goal will be accomplished.

\section{Task 5: Draft, Revise, and Adopt a Plan}

The next step in the process is to draft a plan. The draft plan ties all of the earlier pieces together into a single, cohesive document. In addition, the plan will include detailed steps outlining how, when, and by whom each goal will be addressed. Finally, the plan will include information on how progress will be monitored, achievement measured and results reported.

Just as there is no one "right" way to structure the planning process, there is no "right" way to put a strategic plan into written form. Someone once said "brevity is the soul of clarity." A concise and clearly written report is more likely to be read completely by all interested and involved parties and thus may be more apt to be implemented. The Alliance for Nonprofit Management (1998) suggests the following component parts for a strategic plan:

- Introduction.

- Executive Summary. 
- Mission and Vision Statements (values if part of the plan).

- Organization Profile and History.

- Critical Issues and Strategies.

- Program Goals and Objectives.

- Management Goals and Objectives.

- Appendices.

\section{Task 6: Implement the Plan}

Implementing the plan is the next step in the strategic planning process and it may prove to be the most difficult step in the strategic planning process. Much creative energy and time has been expended in processes, such as developing a mission, vision and goals, and actual adoption of a plan; sometimes the interest of those involved in the process may begin to diminish. However, a great plan with good creative ideas and goals without a specific implementation process is useless.

Implementation of the strategic plan is done in incremental pieces. Typically, strategic plan implementation is done through annual operating plans. These operating plans describe the short-term strategies that define how the overall strategic plan will be implemented during any given operational period (usually the organization's fiscal year). The operational plan serves as the basis and justification for an operating budget request.

The annual operating plan should describe:

- Where the organization is in implementing its strategic plan.

- Which portions of the strategic plan will be implemented during the operating period.

- Where the organization will be at the end of the operational plan period.

- How the operational plan will be implemented (which units/people are responsible?).

- How progress will be measured and reported (what are the annual performance indicators?).
- How the stake holders will be informed and involved.

\section{Summary}

The strategic planning process can be both an exhausting and a time consuming process. At the same time it frequently creates new energy, new ideas and enhanced team work. Maybe even more importantly a strategic planning process provides organizational vision, direction and accountability. It provides the opportunity for the organization, its employees and stakeholders to work toward achieving a shared vision and goals they helped define. Organizations using a strategic planning process often reach a similar conclusion: benefits derived from the process typically exceed any costs incurred.

\section{References}

Alliance Online. 1998. Strategic Planning FAQs. Alliance for Nonprofit Management, Washington, D.C. Retrieved June 28, 1999, online from http://www.allianceonline.org/strategic_planning.html

Alliance Online. 1998. What Are the Basic Steps in a Strategic Planning Process? Alliance for Nonprofit Management, Washington, D.C. Retrieved June 30, 1999, online from http://www.allianceonline.org/clearinghouse/ spfaq3.html.

Alliance Online. 1998. Strategic Planning FAQs. Alliance for Nonprofit Management (1998) Washington, D.C. Retrieved June 28, 1999, online from http://www.allianceonline.org/clearinghouse/ spfaq11.html.

Barry, Bryan, W. 1997. Strategic Planning Workbook for Nonprofit Organizations (Revised and Updated). Saint Paul, MN: Amherst H. Wilder Foundation.

Bryson, John M. 1995. Strategic Planning For Public and Nonprofit Organizations (Revised Edition). San Francisco, CA: Jossey-Bass. 
NSBA. 1998. Strategic Planning Tools. National

School Boards' Association, Washington, D.C.

Retrieved June 15, 2005, online from

http://www.nsba.org/sbot/toolkit/cav.html.

Nanus, Burt. 1992. Visionary Leadership. San

Francisco, CA: Jossey-Bass. 